\title{
Solid State Synthesis and Characterization of Model Hydrodesulfurization Catalysts
}

\author{
M. A. Villa Garcia,* J. Lindner, A. Sachdev, and J. Schwank \\ Department of Chemical Engineering, The University of Michigan, Ann Arbor, Michigan 48109-2136, and \\ *Dpto. Química Organometálica, Facultad de Química, Universidad de Oviedo, Oviedo-33071, Spain
}

Received September 26, 1988; revised May 16, 1989

\begin{abstract}
Solid-state reactions of elemental sulfur with metallic cobalt and molybdenum powders were used to synthesize model catalysts for hydrodesulfurization (HDS). The resulting materials had a general stoichiometry of $\mathrm{Co}_{2 x} \mathrm{Mo}_{1-x} \mathrm{~S}_{2}$ with $x$ between 0.025 and 0.3 . The solid phases formed during synthesis and after exposure to typical HDS reaction conditions were identified by $X$-ray diffraction and selected area electron diffraction. The catalytic activity for hydrodesulfurization of thiophene was tested in a flow reactor. High activity for hydrodesulfurization coincided with the presence of a nonstoichiometric bulk phase. It was found that introducing small quantities of a promoter atom led to similar activity trends, XRD patterns, and electron microscopy results, all of which were attributed to a nonstoichiometric bulk phase. The structure of this phase is not yet fully determined but is consistent with a defect structure of $\mathrm{MoS}_{2}$ having anionic vacancies. 1989 Academic Press, Inc.
\end{abstract}

\section{INTRODUCTION}

Cobalt-molybdena sulfided catalysts are among the most important industrial catalysts for hydrodesulfurization (HDS). The development of HDS catalysts has essentially been empirical, and much research has been done to better understand the catalytic function, especially regarding the role of cobalt as promoter and the nature of the active site. Various models have been proposed to describe the structure of the active phases, and to explain the interactions believed to happen between $\mathrm{MoS}_{2}$ and the Co promoter. The most important models include the "monolayer model" ( $I-$ $3)$, the "intercalation model" $(4,5)$, the "contact synergy" or "remote control model" (6-8), and, in a more recent proposal, the formation of a mixed promoteractive element-S phase ("Co-Mo-S") ( 9 , 10). Despite considerable progress in basic knowledge about HDS catalysts, the various models still leave some open questions about the function of Co $(11,12)$. Based on the recently developed "Co-Mo-S" model, a correlation was proposed between the amount of the "Co-Mo-S phase" and the HDS activity for either supported (10, 13) or unsupported (14) Co-Mo sulfided catalysts.

To obtain a more detailed insight into the structure and the physicochemical properties of Co-Mo-S, Co-promoted HDS catalysts were extensively studied by a variety of techniques including Mössbauer emission spectroscopy $(9,15)$, X-ray photoelectron spectroscopy $(16,17)$, EXAFS (1820 ), analytical and high resolution electron microscopy (21-23), X-ray diffraction (23), infrared spectroscopy (24), and EPR (25, 26) among others. From these results it was inferred that Co-Mo-S has a $\mathrm{MoS}_{2}$-like structure, with $\mathrm{Co}$ atoms being at the edges of the $\mathrm{MoS}_{2}$ crystallites, probably in substitutional positions. The EXAFS results ( $18-$ 20) showed a coordination of Co with six sulfurs in an octahedral surrounding, but not in the form of a bulk sulfide, with Co-S distances shorter than Mo-S distances. The EPR signal of the Co-Mo-S structure suggested the existence of $\mathrm{Co}^{2+}$ centers interacting with $\mathrm{Mo}^{4+}$ neighboring centers (26). It was also shown that the formation 
of Co-Mo-S structures was strongly dependent on the catalyst preparation procedures $(9,12,23)$. The sulfiding conditions and the Co content also had a significant influence on the formation of these active phases $(12,27,28)$.

Although this research has greatly improved our understanding of Co-promoted HDS catalysts, the exact nature of the active site is still not fully resolved. It has not yet been elucidated whether the HDS activity of Co-Mo-S can simply be related to anion vacancies associated with the Co edge atoms or whether the neighboring Mo edge atoms also play a direct role $(12,28$, 29). Also, there are many unanswered questions about the structure of Co-Mo-S. Are they surface species formed under reaction conditions? Can one consider them as phases in a crystallographic sense? If the latter were the case, and if Co-Mo-S does not exhibit an intercalation structure (12), then Co-Mo-S could represent one of the following structural compounds: (i) a binary Co-Mo sulfide; (ii) a solid solution isostructural with $\mathrm{MoS}_{2}$ that would form during the sulfiding treatment, preferentially at the edges of the $\mathrm{MoS}_{2}$ crystallites where the reactivity is higher because of greater defect concentrations; (iii) a mixture of $\mathrm{MoS}_{2}$ and Co sulfides different from the thermodynamically stable $\mathrm{Co}_{9} \mathrm{~S}_{8}$.

Until now the methods used for the synthesis of HDS catalysts, e.g., the comaceration method (6), the homogeneous sulfide precipitation method (23), the coprecipitation method (30) and their variants, tend to lead to the formation of amorphous or poorly crystalline materials containing low amounts of Co-Mo-S. Farragher and Cossee (5) reported using a solid state synthesis procedure to form $\mathrm{MoS}_{2}$ and $\mathrm{WS}_{2}$ hydrogenation catalysts. These authors also attempted to incorporate $\mathrm{Ni}$ into the $\mathrm{WS}_{2}$ structure by heating the elements at $1173 \mathrm{~K}$ and found that the presence of $\mathrm{Ni}$ induced a random faceting of the surface. They suggested surface reconstruction induced by $\mathrm{Ni}$ or $\mathrm{Co}$. However, their synthe- sis temperature was $1173 \mathrm{~K}$ and they did not investigate the HDS potential of their materials.

The present paper reports the results of our attempt to grow bulk Co-Mo-S phases that would show the same structure and activity as the active ones found in HDS catalysts. The synthesis of these phases was based on solid state reactions of elemental sulfur with metallic Co and Mo powders. These bulk phases are easier to characterize than those in conventional supported HDS catalysts. Therefore, they offer a better opportunity for establishing correlations between stoichiometry, structure, and activity.

\section{EXPERIMENTAL}

Sample preparation. A series of samples with different $\mathrm{Co} / \mathrm{Mo}$ ratios and a general stoichiometry of $\mathrm{Co}_{2 x} \mathrm{Mo}_{1-x} \mathrm{~S}_{2}$, where $x$ was between 0.025 and 0.3 , were prepared by combining stoichiometric amounts of elemental cobalt and molybdenum powders with elemental sulfur, all three chemicals used being Fluka products (purum). The powders were throughly mixed by grinding them together to insure intimate contact between the components. The mixtures were placed into quartz tubes which were then evacuated to about $0.1 \mathrm{~Pa}$ and sealed. The tubes containing the mixtures were heated at a heating rate of $10 \mathrm{~K}$ per min from room temperature to $783 \mathrm{~K}$, held at this temperature for $24 \mathrm{~h}$, and then rapidly quenched. Once the treatment was finished, the quartz tubes were opened. The contents of the tubes, generally dark grey or black materials, were removed and, if necessary, ground into fine powders. All the sulfur was reacted as there was no visible evidence of elemental sulfur in the tubes after the synthesis.

On the basis of the amounts of elemental powders used for the synthesis, the samples were named $\mathrm{Co}_{0.05} \mathrm{Mo}_{0.975} \mathrm{~S}_{2}, \mathrm{Co}_{0.1}$ $\mathrm{Mo}_{0.95} \mathrm{~S}_{2}, \mathrm{Co}_{0.2} \mathrm{Mo}_{0.9} \mathrm{~S}_{2}, \mathrm{Co}_{0.3} \mathrm{Mo}_{0.85} \mathrm{~S}_{2}, \mathrm{Co}_{0.5}$ $\mathrm{Mo}_{0.75} \mathrm{~S}_{2}$, and $\mathrm{Co}_{0.6} \mathrm{Mo}_{0.7} \mathrm{~S}_{2}$. Unpromoted $\mathrm{MoS}_{2}$ and a nonstoichiometric sample, 
$\mathrm{MoS}_{1.95}$, were also prepared from a mixture of metallic molybdenum and elemental sulfur following the procedure mentioned above.

Furthermore, a mechanical mixture of metallic $\mathrm{Co}$ and Mo powders with a $\mathrm{Co} / \mathrm{Mo}$ atomic ratio of 0.222 was prepared and then sulfided under standard presulfiding conditions for conventional catalysts $(673 \mathrm{~K}$ for $24 \mathrm{~h}$ in a flow of $2 \% \mathrm{H}_{2} \mathrm{~S} / \mathrm{H}_{2}$ ). This sample was named " $\mathrm{Co}_{0.2} \mathrm{Mo}_{0.9}+\mathrm{H}_{2} \mathrm{~S}$."

Catalyst characterization. To determine the crystalline phases present, all the catalysts were characterized by X-ray diffraction. A Phillips PW-1729 powder diffractometer equipped with a graphite crystal monochromator and $\mathrm{Cu} K \alpha$ radiation was used. The surface areas of the freshly prepared samples were determined by using the BET method and a Monosorb Quantachrome single point instrument with nitrogen as adsorbate.

Electron microscopy was used to obtain selected area electron diffraction patterns of small regions of the catalysts and complement the X-ray diffraction study. A JEOL 2000FX microscope operating at 200 $\mathrm{kV}$ was utilized for this purpose. Selected area diffraction patterns were obtained from regions $20 \mu \mathrm{m}$ in diameter. Specimens were prepared by crushing the catalyst powder and then suspending it in isopropyl alcohol by sonicating the resulting mixture for $10 \mathrm{~min}$. A few drops of this suspension were applied to a holey carbon support film on a copper grid.

X-ray photoelectron spectroscopy was used primarily as a purity check to insure that no trace amounts of transition metals were present in the $\mathrm{MoS}_{2}$ and $\mathrm{MoS}_{1.95}$ samples and to monitor the chemical shifts and peak shape of the Co $2 p_{1 / 2}$ and $2 p_{3 / 2}$ signals. A Perkin-Elmer 5400 Series spectrometer was used with an $\mathrm{Al}$ anode operating at a pass energy of $71.5 \mathrm{eV}$. Spectra were recorded in the multiplex acquisition format in steps of $0.2 \mathrm{eV}$ and the $\mathrm{C} 1 s(284.6 \mathrm{eV})$ signal arising from airborne impurities present on all samples was used as an inter- nal standard for binding energy calibration.

Activity measurements. The catalytic activity for the hydrodesulfurization of thiophene (Aldrich 99+\%, Gold Label) was measured in a $\frac{1}{4}$-in.-diameter stainless-steel continuous-flow reactor. The powdered catalyst $(0.35 \mathrm{~g})$ was loaded into the reactor and the temperature raised to $673 \mathrm{~K}$ under a flow of high-purity helium at $30 \mathrm{ml}$ per min and held at $673 \mathrm{~K}$ for $30 \mathrm{~min}$. Then, the temperature was lowered to the desired reaction temperature, typically between 473$673 \mathrm{~K}$. The He flow was replaced by a gaseous feed stream containing $2.7 \%$ (by volume) of thiophene, the balance being hydrogen, at a flow rate of $10 \mathrm{ml}$ per minute and a pressure of $98.6 \mathrm{kPa}$. The high-purity $\mathrm{He}$ and $\mathrm{H}_{2}$ ( $<49$ ppm impurities) were further purified by passage through a commercial oxygen trap (Matheson) and a bed of molecular sieves $(5 \AA)$ to remove moisture.

All samples were on stream a minimum of $20 \mathrm{~h}$ and steady-state conversions were obtained after 40-45 min on stream. There was no noticeable change in activity of the Co-containing samples after $80 \mathrm{~h}$ on stream at $673 \mathrm{~K}$. The effluent from the reactor was analyzed every half-hour by gas chromatography. Product separation and analysis were performed by using an $n$-octane/Porasil $\mathrm{C}$ column in a Varian 3700 gas chromatography equipped with thermal conductivity detector. Peak areas were determined by a Hewlett-Packard 3390A integrator. After a given catalytic run the catalyst bed was flushed with $\mathrm{He}$ gas at $673 \mathrm{~K}$.

\section{RESULTS AND DISCUSSION}

Figures 1 and 2 show relevant parts of the $\mathrm{X}$-ray powder diffraction patterns of the fresh catalysts before being used in the HDS reaction. Also included are the diffractograms of the model compounds $\mathrm{MoS}_{2}, \mathrm{MoS}_{1.95}$ and of sample " $\mathrm{Co}_{0.2} \mathrm{Mo}_{0.9}+$ $\mathrm{H}_{2} \mathrm{~S}$." The diffraction patterns of the used catalysts after $80 \mathrm{~h}$ on stream in thiophene hydrodesulfurization are given in Fig. 3. Vertical lines mark the positions of the diffraction maxima corresponding to the dif- 


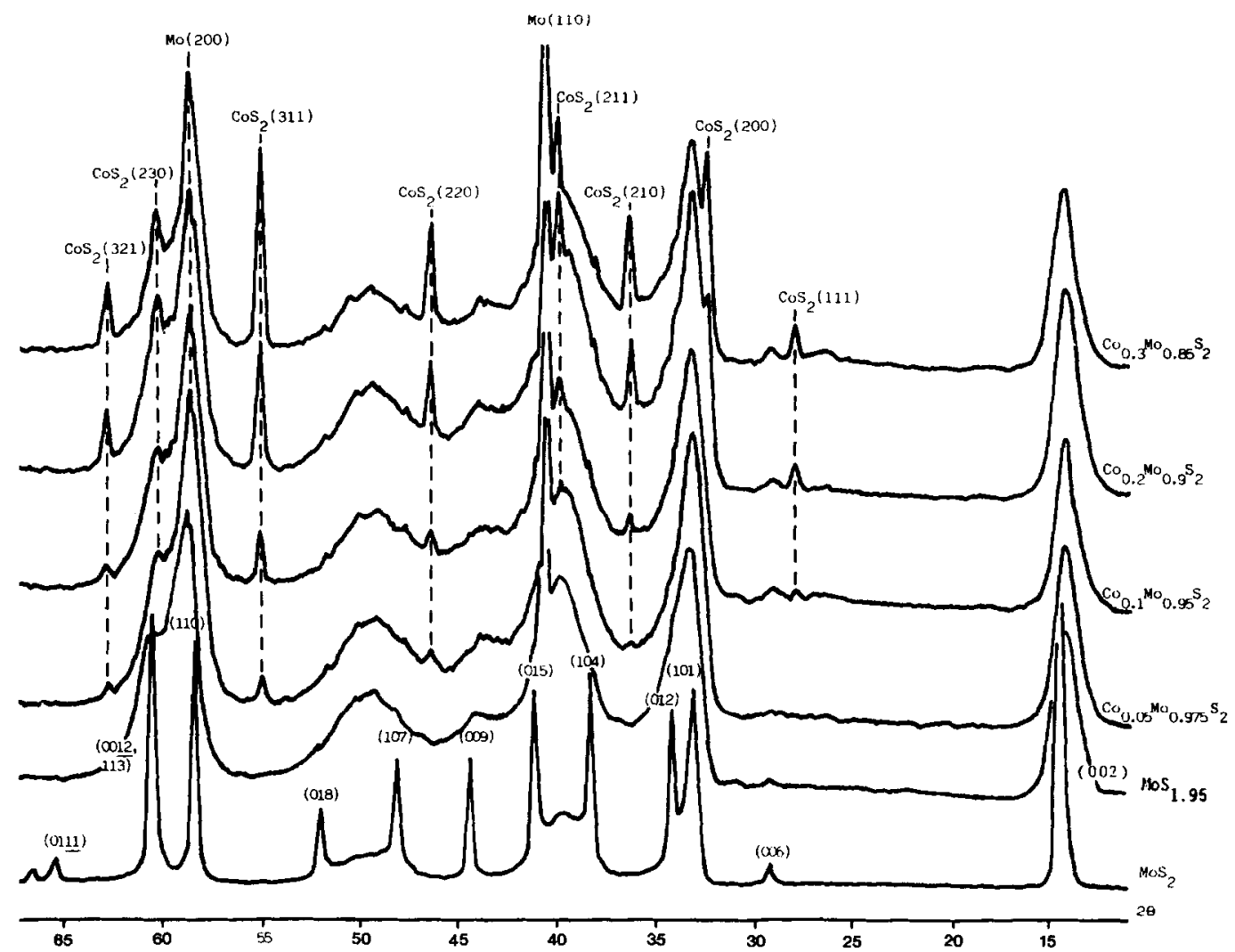

FIG. 1. X-ray diffraction patterns of freshly prepared catalysts $\mathrm{Co}_{0.05} \mathrm{Mo}_{0.975} \mathrm{~S}_{2}, \mathrm{Co}_{0.1} \mathrm{Mo}_{0.95} \mathrm{~S}_{2}, \mathrm{Co}_{0.2}$ $\mathrm{Mo}_{0.9} \mathrm{~S}_{2}$, and $\mathrm{Co}_{0.3} \mathrm{Mo}_{0.85} \mathrm{~S}_{2}$. For comparison, the diffraction pattern of $\mathrm{MoS}_{2}$ is also shown.

ferent phases. The powder X-ray diffraction patterns shown in Figs. 1, 2, and 3 show that all the catalysts consist of a mixture of crystalline phases. In Table 1, the BET surface areas and the crystalline phases found in the fresh and used catalysts are summarized.

The samples $\mathrm{Co}_{0.05} \mathrm{Mo}_{0.975} \mathrm{~S}_{2}, \mathrm{Co}_{0.1} \mathrm{Mo}_{0.95}$ $\mathrm{S}_{2}, \mathrm{Co}_{0.2} \mathrm{Mo}_{0.9} \mathrm{~S}_{2}$, and $\mathrm{Co}_{0.3} \mathrm{Mo}_{0.85} \mathrm{~S}_{2}$ (Fig. 1) exhibited very similar X-ray diffraction patterns. The patterns could be deconvoluted into three distinct contributions of (1) unreacted metallic Mo, (2) $\mathrm{CoS}_{2}$ with a cubic pyrite-type structure, and (3) a phase exhibiting broad diffraction lines. $\mathrm{CoS}_{2}$ showed a progressive growth with increasing Co loadings going from $\mathrm{Co}_{0.05} \mathrm{Mo}_{0.975} \mathrm{~S}_{2}$ to $\mathrm{Co}_{0.3}$ $\mathrm{Mo}_{0.85} \mathrm{~S}_{2}$.

The maxima and line widths of the third phase found in these catalysts corresponded with those of the nonstoichiometric $\mathrm{MoS}_{1.95}$ sample which also contained some unreacted metallic molybdenum. Compared to stoichiometric $\mathrm{MoS}_{2}$, there were differences in the intensities of reflections from certain crystallographic planes. The (002) diffraction line which was the most intense one in the model $\mathrm{MoS}_{2}$ compound, lost intensity along with the (104) and the $(0012,113)$ lines, while the (101) and (110) reflections became more intense than those in $\mathrm{MoS}_{2}$. This phenomenon is characteristic of all the processes involving changes in the composition of a material by isomorphic replacement, here replacement of $\mathrm{Mo}$ ions by $\mathrm{Co}$ ions. If $\mathrm{Mo}^{4+}$ cations in the $\mathrm{MoS}_{2}$ lattice are replaced by Co cations having lower charge, then the charge bal- 


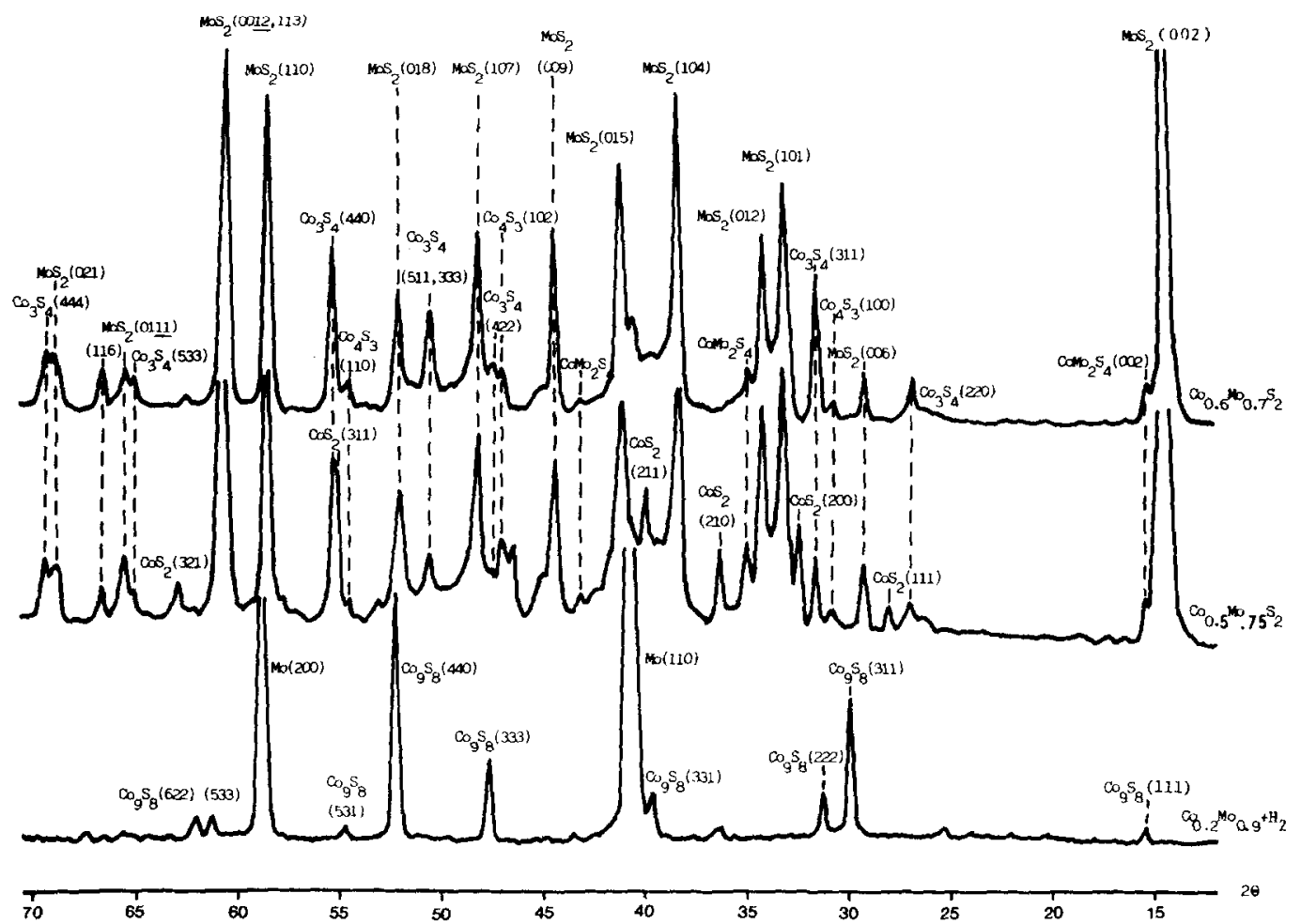

FIG. 2. X-ray diffraction patterns of freshly prepared catalysts $\mathrm{Co}_{0.5} \mathrm{Mo}_{0.75} \mathrm{~S}_{2}$ and $\mathrm{Co}_{0.6} \mathrm{Mo}_{0.7} \mathrm{~S}_{2}$, and of the mechanical mixture " $\mathrm{Co}_{0.2} \mathrm{Mo}_{0.9}+\mathrm{H}_{2} \mathrm{~S}$."

TABLE 1

BET Surface Areas and Phases Detected in XRD

\begin{tabular}{|c|c|c|c|c|}
\hline \multirow[t]{2}{*}{ Catalyst } & \multirow{2}{*}{$\begin{array}{c}\mathrm{Co} / \mathrm{Mo} \\
\text { (atomic ratio) }\end{array}$} & \multirow{2}{*}{$\begin{array}{c}\text { BET } \\
\text { surface } \\
\text { area } \\
\left(\mathrm{m}^{2} / \mathrm{g}\right)\end{array}$} & \multicolumn{2}{|c|}{ Crystalline phases } \\
\hline & & & Fresh catalyst & Used catalyst \\
\hline $\mathrm{Co}_{0.05} \mathrm{Mo}_{0.975} \mathrm{~S}_{2}$ & 0.051 & 26 & $\mathrm{~A}^{a}+\mathrm{Mo}+\mathrm{CoS}_{2}$ & $\mathrm{Mo}+\mathrm{A}, \mathrm{CoO}(\mathrm{OH})^{b}$ \\
\hline $\mathrm{Co}_{0.1} \mathrm{Mo}_{0.95} \mathrm{~S}_{2}$ & 0.105 & 14 & $\mathrm{~A}+\mathrm{Mo}+\mathrm{CoS}_{2}$ & $\mathrm{Mo}+\mathrm{A}, \mathrm{CoO}(\mathrm{OH})$ \\
\hline $\mathrm{Co}_{0.2} \mathrm{Mo}_{0.9} \mathrm{~S}_{2}$ & 0.222 & 14 & $\mathrm{~A}+\mathrm{Mo}+\mathrm{CoS}_{2}$ & $\begin{array}{l}\mathrm{Mo}+\mathrm{A}+\mathrm{Co}_{9} \mathrm{~S}_{8} \\
+\mathrm{CoO}(\mathrm{OH})\end{array}$ \\
\hline $\mathrm{Co}_{0.3} \mathrm{Mo}_{0.85} \mathrm{~S}_{2}$ & 0.353 & 15 & $\mathrm{~A}+\mathrm{Mo}+\mathrm{CoS}_{2}$ & $\begin{array}{l}\mathrm{Mo}+\mathrm{A}+\mathrm{Co}_{9} \mathrm{~S}_{8} \\
\quad+\mathrm{CoO}(\mathrm{OH})\end{array}$ \\
\hline $\mathrm{Co}_{0.5} \mathrm{Mo}_{0.75} \mathrm{~S}_{2}$ & 0.667 & 1 & $\begin{array}{l}\mathrm{MoS}_{2}+\mathrm{CoS}_{2}+\mathrm{Co}_{3} \mathrm{~S}_{4} \\
\quad+\mathrm{Co}_{4} \mathrm{~S}_{3}+\mathrm{CoMo}_{2} \mathrm{~S}_{4}+\mathrm{Mo}\end{array}$ & $\begin{array}{l}\mathrm{MoS}_{2}+\mathrm{Co}_{9} \mathrm{~S}_{8} \\
\quad+\mathrm{Co}_{3} \mathrm{~S}_{4}+\mathrm{CoMo}_{2} \mathrm{~S}_{4}+\mathrm{Mo}\end{array}$ \\
\hline $\mathrm{Co}_{0.6} \mathrm{Mo}_{0.7} \mathrm{~S}_{2}$ & 0.8571 & 1 & $\begin{array}{l}\mathrm{MoS}_{2}+\mathrm{Co}_{3} \mathrm{~S}_{4}+\mathrm{Co}_{4} \mathrm{~S}_{3} \\
+\mathrm{CoMo}_{2} \mathrm{~S}_{4}+\mathrm{Mo}\end{array}$ & $\begin{array}{l}\mathrm{MoS}_{2}+\mathrm{Co}_{9} \mathrm{~S}_{8} \\
\quad+\mathrm{Co}_{3} \mathrm{~S}_{4}+\mathrm{CoMo}_{2} \mathrm{~S}_{4}+\mathrm{Mo}\end{array}$ \\
\hline $\mathrm{Co}_{0.2} \mathrm{Mo}_{0.9}+\mathrm{H}_{2} \mathrm{~S}$ & 0.222 & 1 & $\mathrm{Mo}+\mathrm{Co}_{9} \mathrm{~S}_{8}$ & $\mathrm{Mo}+\mathrm{Co}_{9} \mathrm{~S}_{8}$ \\
\hline $\mathrm{MoS}_{2}$ & 0 & 1 & $\mathbf{M o S}_{2}$ & $\operatorname{MoS}_{2}$ \\
\hline $\operatorname{MoS}_{1.95}$ & 0 & 20 & $\mathrm{MoS}_{2}+\mathrm{Mo}$ & $\mathrm{MoS}_{2}+\mathrm{Mo}$ \\
\hline
\end{tabular}

a "A" is a nonstoichiometric bulk phase.

${ }^{b}$ The phases in italics are present in only minor proportion or as traces. 


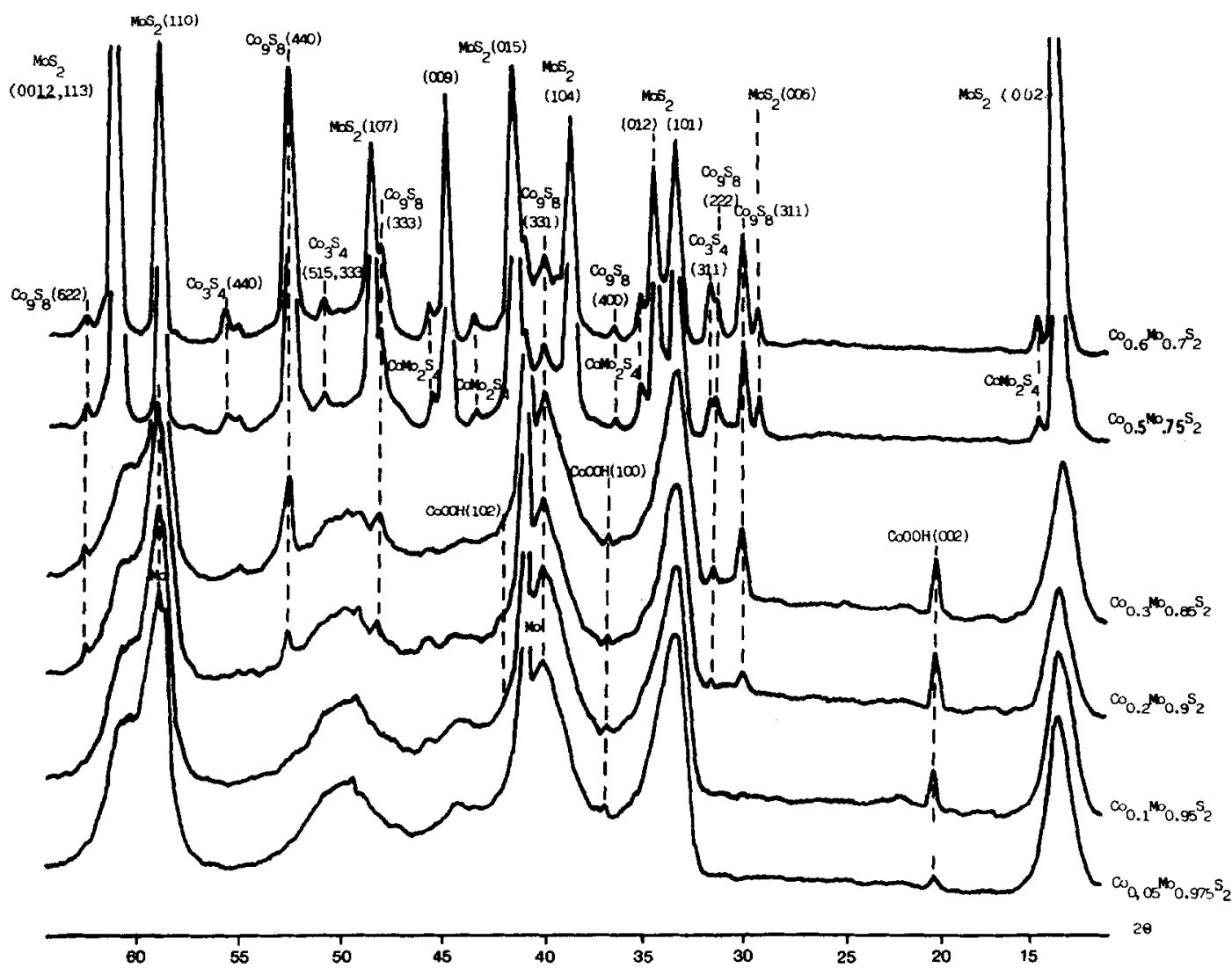

Fig. 3. X-ray diffraction patterns of catalysts $\mathrm{Co}_{0.05} \mathrm{Mo}_{0.975} \mathrm{~S}_{2}, \mathrm{Co}_{0.1} \mathrm{Mo}_{0.95} \mathrm{~S}_{2}, \mathrm{Co}_{0.2} \mathrm{Mo}_{0.9} \mathrm{~S}_{2}, \mathrm{Co}_{0.3} \mathrm{Mo}_{0.85}$ $\mathrm{S}_{2}, \mathrm{Co}_{0.5} \mathrm{Mo}_{0.75} \mathrm{~S}_{2}$, and $\mathrm{Co}_{0.6} \mathrm{Mo}_{0.7} \mathrm{~S}_{2}$ after prolonged exposure to typical hydrodesulfurization reaction conditions in a flow reactor.

ance in the lattice may be maintained by creating anionic vacancies. The "substitutional solid solution" formed would be nonstoichiometric. Seeing that the creation of anionic sulfur vacancies in $\mathrm{MoS}_{2}$ resulted in $\mathrm{X}$-ray line broadening, it is tempting to attribute the line broadening in the cobaltcontaining samples also to the lack of stoichiometry.

It is important to recognize that the broadening of the XRD lines in the $\mathrm{MoS}_{1.95}$ sample should not be attributed solely to a smaller particle size associated with a higher surface area. Electron micrographs revealed that the average particle size for both of these materials is essentially constant. Furthermore, it is well known that the presence of vacancies, in our case sul- fur vacancies, is often indicative of a highly defective material rather than of a sample consisting of many small crystallites diffracting incoherently with respect to each other (31).

It has been suggested in the literature that one of the major roles of cobalt is to increase the dispersion of very small particles of $\mathrm{MoS}_{2}(32,33)$ resulting in X-ray line broadening. However, in the case of the solid state samples investigated here, the $\mathrm{X}$-ray line broadening cannot be attributed solely to crystallite size effects, but is due to defects in the material. This phase also exhibits a lower degree of crystallinity. The evidence for this comes from selected area electron diffraction. $\mathrm{MoS}_{2}$ showed very definite crystalline spot patterns from all re- 

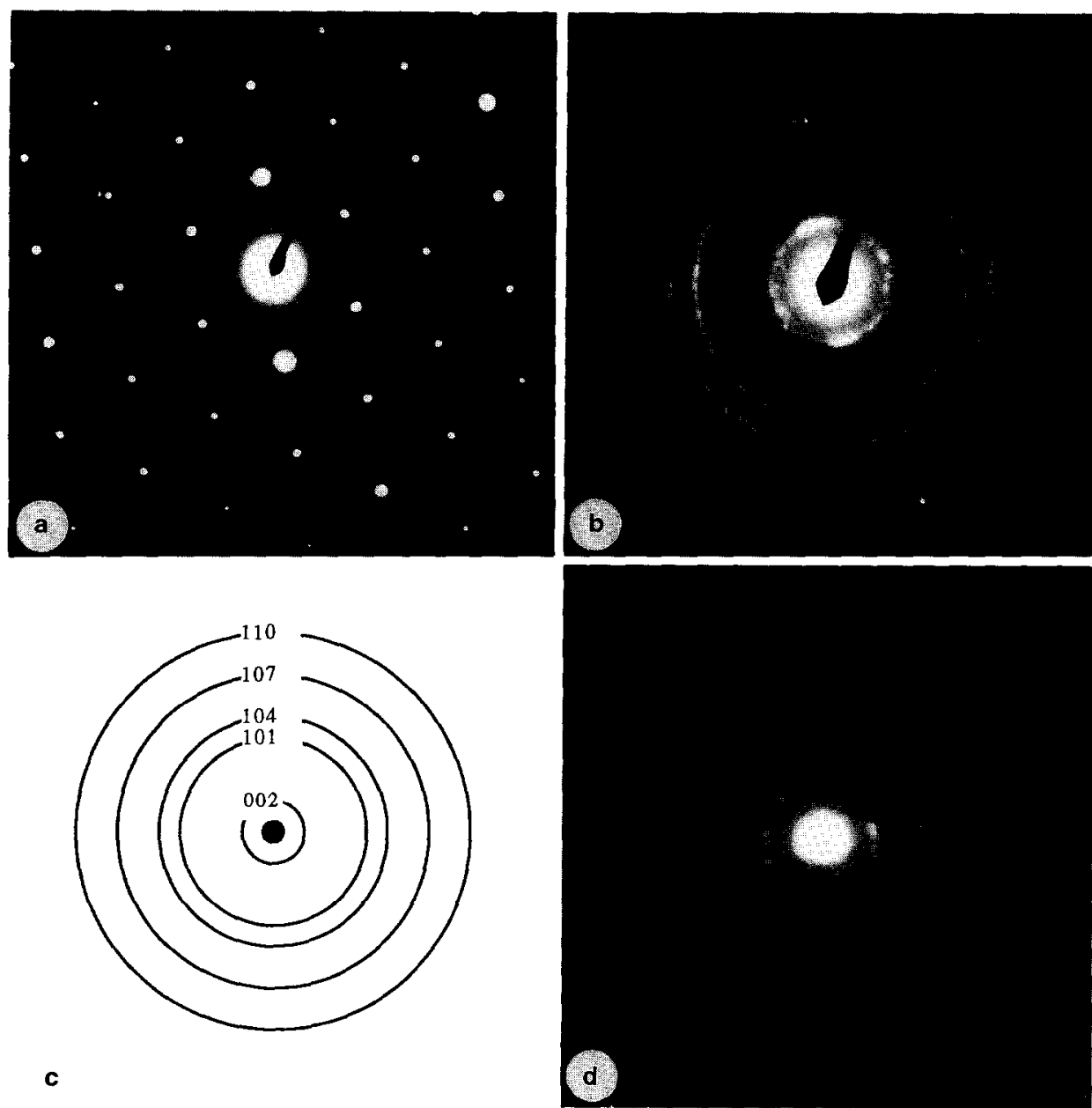

FIG. 4. (a) Selected area electron diffraction (SAED) pattern of $\mathrm{MoS}_{2}$ showing well-defined crystalline spots taken from a zone axis of [121]. (b) SAED pattern from nonstoichiometric MoS $_{1.95}$ showing diffraction rings indicating its polycrystalline nature. (c) Indexed ring pattern from $M_{0} S_{1.95}$ and $\mathrm{Co}_{0.05} \mathrm{Mo}_{0.975} \mathrm{~S}_{2}$. The (002), (101), and (104) reflections have the greatest intensities. (d) SAED pattern of $\mathrm{Co}_{0.05} \mathrm{Mo}_{0.975} \mathrm{~S}_{2}$ showing diffraction ring structures similar to those observed for the nonstoichiometric $\mathrm{MoS}_{1.95}$ compound.

gions of the sample investigated (Fig. 4a). The nonstoichiometric $\mathrm{MoS}_{1.95}$ sample gave a ring structure showing predominantly (002), (101), and (104) reflections (Fig. 4b and $4 \mathrm{c})$. The ring patterns indicate that the sample is polycrystalline throughout. Selected area electron diffraction of $\mathrm{Co}_{0.05}$ $\mathrm{Mo}_{0.975} \mathrm{~S}_{2}$ showed ring diffraction patterns strikingly similar to those visible in the nonstoichiometric $\mathrm{MoS}_{1.95}$ sample (Fig. 4d). The close resemblance of the X-ray and electron diffraction patterns of $\mathrm{MoS}_{1.95}$ and
$\mathrm{Co}_{0.05} \mathrm{Mo}_{0.975} \mathrm{~S}_{2}$ strongly suggests the presence of a nonstoichiometric phase also in the cobalt-containing catalyst. A more detailed structural characterization of this new phase based on high-resolution and analytical electron microscopy is published elsewhere (34) and fully confirms the presence of defects on an atomic scale.

For the time being, we have relied on the $X$-ray diffraction patterns to obtain a first estimate of the $d$ spacings using silicon as internal standard to analyze the (002) and 
(101) reflections. The broadening of the other lines made it very difficult to obtain $d$ spacing values. Compared to the model $\mathrm{MoS}_{2}$ with $d$ spacings of 6.1122 and 2.7081 for the (002) and (101) lines, values of 6.27081 and 2.7170 were obtained for the $\mathrm{Co}_{0.1} \mathrm{Mo}_{0.95} \mathrm{~S}_{2}$ sample, indicating an expansion of the unit cell.

Samples $\mathrm{Co}_{0.5} \mathrm{Mo}_{0.75} \mathrm{~S}_{2}$ and $\mathrm{Co}_{0.6} \mathrm{Mo}_{0.7} \mathrm{~S}_{2}$ had more complex $\mathrm{X}$-ray diffraction patterns (Fig. 2), showing the presence of a mixture of $\mathrm{MoS}_{2}$, traces of metallic Mo, and various cobalt sulfides including $\mathrm{Co}_{3} \mathrm{~S}_{4}$, $\mathrm{Co}_{4} \mathrm{~S}_{3}$, and $\mathrm{CoMo}_{2} \mathrm{~S}_{4}$. The sample $\mathrm{Co}_{0.5}$ $\mathrm{Mo}_{0.75} \mathrm{~S}_{2}$ also contained some $\mathrm{CoS}_{2}$. As can be seen from Table 1, the presence of the defective $\mathrm{MoS}_{2}$-based phase depends on the cobalt content, as it is observed only in those catalysts with a $\mathrm{Co} / \mathrm{Mo}$ atomic ratio smaller than 0.5 while the samples $\mathrm{Co}_{0.5}$ $\mathrm{Mo}_{0.75} \mathrm{~S}_{2}$ and $\mathrm{Co}_{0.6} \mathrm{Mo}_{0.7} \mathrm{~S}_{2}$ with a $\mathrm{Co} / \mathrm{Mo}$ ratio $\geq 0.5$ do not exhibit that phase.

The diffraction patterns of sample " $\mathrm{Co}_{0.2}$ $\mathrm{Mo}_{0.9}+\mathrm{H}_{2} \mathrm{~S}$ " (Fig. 2) showed the presence of two phases, metallic Mo inert to the sulfiding treatment under an $\mathrm{H}_{2} \mathrm{~S} / \mathrm{H}_{2}$ flow at $673 \mathrm{~K}$ and $\mathrm{Cog}_{9} \mathrm{~S}_{8}$ which is the thermodynamically stable cobalt sulfide phase.

On the basis of X-ray diffraction patterns of the used catalysts, given in Fig. 3, $\mathrm{Co}_{0.05}$ $\mathrm{Mo}_{0.975} \mathrm{~S}_{2}$ and $\mathrm{Co}_{0.1} \mathrm{Mo}_{0.95} \mathrm{~S}_{2}$ contained only metallic $M o$ and the nonstoichiometric phase while $\mathrm{Co}_{0.2} \mathrm{Mo}_{0.9} \mathrm{~S}_{2}$ and $\mathrm{Co}_{0.3} \mathrm{Mo}_{0.85} \mathrm{~S}_{2}$ contained $\mathrm{Co}_{9} \mathrm{~S}_{8}$ as well. It seems that under reaction conditions and in the presence of higher amounts of cobalt the $\mathrm{CoS}_{2}$ phase is transformed into the thermodynamically stable $\mathrm{Co}_{9} \mathrm{~S}_{8}$ phase. These four used catalysts also showed very small traces of cobalt oxide hydroxide. It is highly unlikely that this cobalt oxide hydroxide plays a significant role in the HDS activity. Since the cobalt hydroxide phase only appears in the used catalysts, it is safe to assume that this phase is formed under reaction conditions. The samples $\mathrm{Co}_{0.5} \mathrm{Mo}_{0.75} \mathrm{~S}_{2}$ and $\mathrm{Co}_{0.6} \mathrm{Mo}_{0.7} \mathrm{~S}_{2}$ consisted of a mixture of $\mathrm{MoS}_{2}, \mathrm{Co}_{9} \mathrm{~S}_{8}$, and very small amounts of $\mathrm{Co}_{3} \mathrm{~S}_{4}$ and $\mathrm{CoMo}_{2} \mathrm{~S}_{4}$. Traces of metallic Mo were also detected.
The temperature dependence of HDS activity of all the model catalysts is presented in Fig. 5. Within the series of $\mathrm{Co}_{2 x} \mathrm{Mo}_{1-x} \mathrm{~S}_{2}$ catalysts, $\mathrm{Co}_{0.05} \mathrm{Mo}_{0.975} \mathrm{~S}_{2}, \mathrm{Co}_{0.1} \mathrm{Mo}_{0.95} \mathrm{~S}_{2}$, $\mathrm{Co}_{0.2} \mathrm{Mo}_{0.9} \mathrm{~S}_{2}$, and $\mathrm{Co}_{0.3} \mathrm{Mo}_{0.85} \mathrm{~S}_{2}$ had significantly higher activities than $\mathrm{Co}_{0.5} \mathrm{Mo}_{0.75} \mathrm{~S}_{2}$ and $\mathrm{Co}_{0.6} \mathrm{Mo}_{0.7} \mathrm{~S}_{2}$. These highly active catalysts containing the nonstoichiometric phase are grouped together in the shaded area on top of the plot, together with the data for the nonstoichiometric $\operatorname{MoS}_{1.95}$ sample. The less active Co-promoted samples are grouped in the cross-hatched area below, and the physical mixture and $\mathrm{MoS}_{2}$ lie below this region. To further simplify the comparison among different samples, the activity at $573 \mathrm{~K}$ is plotted as a function of the $\mathrm{Co} / \mathrm{Mo}$ ratio (Fig. 6).

High HDS activity of the Co-containing catalysts coincided with the observation of $\mathrm{X}$-ray and electron diffraction patterns indicative of the new nonstoichiometric phase (Figs. 1, 2, 5, and 6) resembling that found in $\mathrm{MoS}_{1.95}$. The less active samples $\mathrm{Co}_{0.5} \mathrm{Mo}_{0.75} \mathrm{~S}_{2}, \mathrm{Co}_{0.6} \mathrm{Mo}_{0.7} \mathrm{~S}_{2},{ }^{\prime \prime} \mathrm{Co}_{0.2} \mathrm{Mo}_{0.9}+$ $\mathrm{H}_{2} \mathrm{~S}$," and the stoichiometric $\mathrm{MoS}_{2}$ sample did not contain detectable amounts of the new phase.

The Co-promoting effect appears to be linked to the sulfur vacancies created to maintain the charge balance during the partial replacements of Mo ions in the $\mathrm{MoS}_{2}$ lattice by lower charged Co ions. However, it should be noted that a significant activity enhancement can be achieved in absence of cobalt by directly introducing anionic sulfur vacancies into $\mathrm{MoS}_{2}$ (see the activity data for sample $\operatorname{MoS}_{1.95}$ in Figs. 5 and 6). Of course, this does not rule out that cobalt has an additional promoting role beyond the effect of creating nonstoichometry in molybdenum sulfide. XPS confirmed that the $\mathrm{MoS}_{1.95}$ sample contained only molybdenum and sulfur with small amounts of carbon and oxygen. The XPS spectra for the Co-containing catalysts were similar in appearance except for the presence of wellresolved Co $2 p_{1 / 2}$ and Co $2 p_{3 / 2}$ peaks.

The samples with very high activity also 


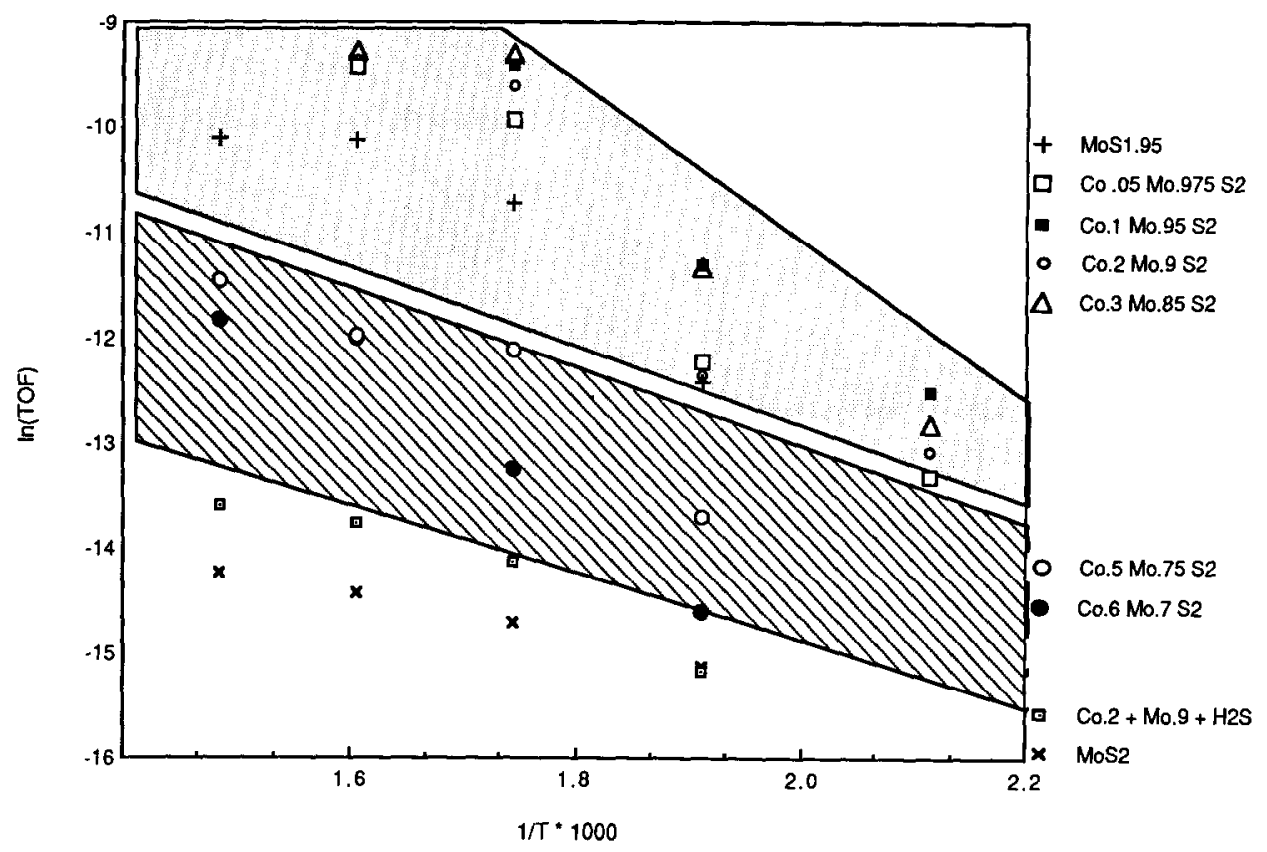

FIG. 5. Plot of HDS activity (ln(TOF)) vs $1 / T$ for model catalysts. The turnover frequencies shown are normalized on the basis of thiophene molecules converted per Mo atom in the catalyst per $\mathrm{s}$.

had much greater surface areas than the samples with lower activities. However, a normalization of activity based on surface area would not be meaningful in view of the well-known lack of correlation between HDS activity and surface area. Our results corroborate this lack of correlation. Samples with nearly identical surface areas have almost an order of magnitude difference in activity (see Figs. 5 and 6 and Table 1). This can be seen by comparing the $\mathrm{Co}_{0.5}$ $\mathrm{Mo}_{0.75} \mathrm{~S}_{2}$ and $\mathrm{Co}_{0.6} \mathrm{Mo}_{0.7} \mathrm{~S}_{2}$ samples with the

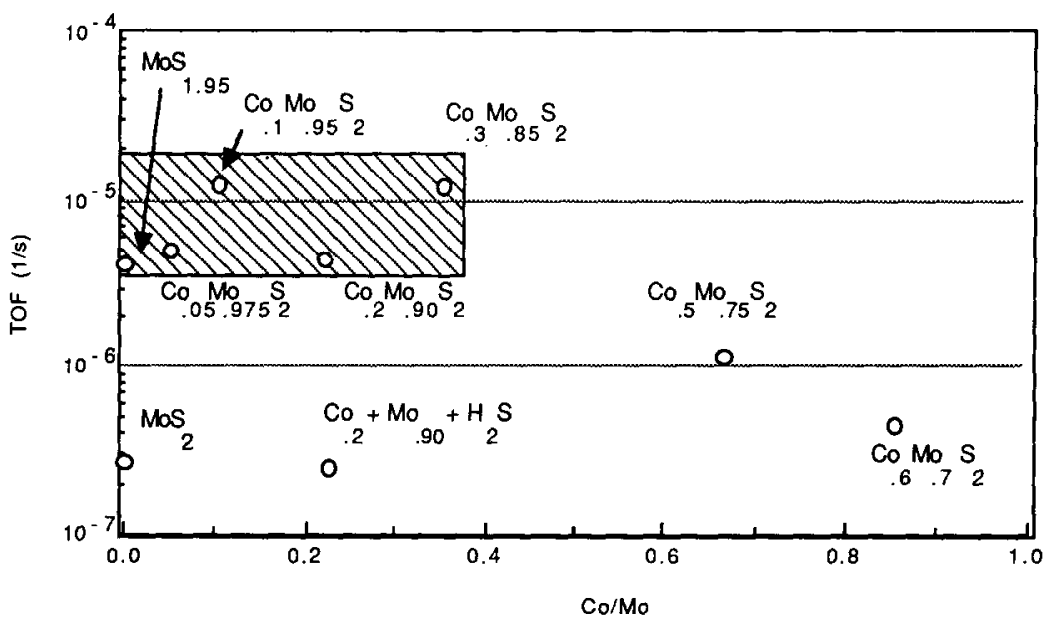

FIG. 6. Thiophene hydrodesulfurization activity at $573 \mathrm{~K}$ as a function of the Co/Mo ratio in the model catalysts. 


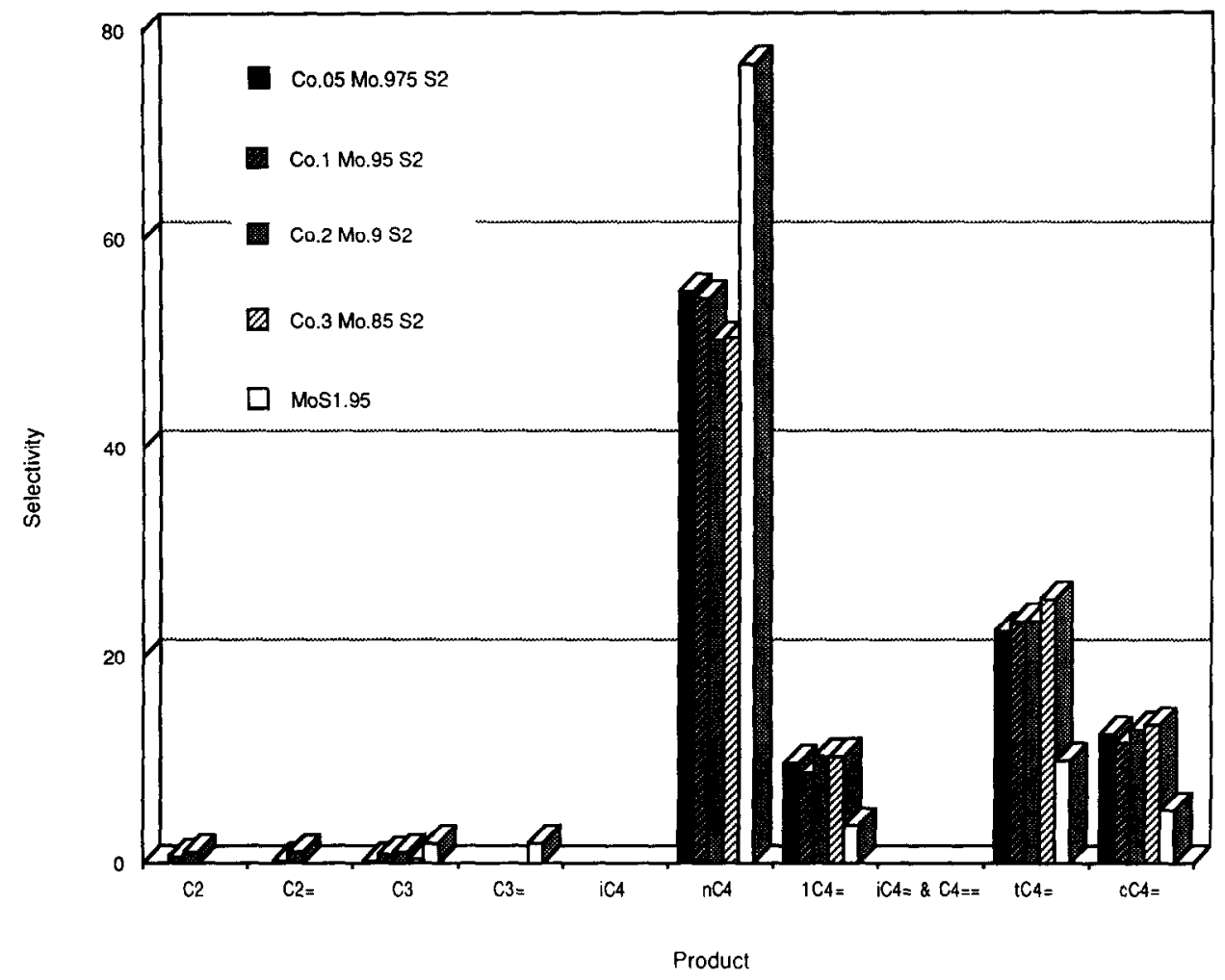

Fig. 7. Selectivity for $C_{2}, C_{3}$, and $C_{4}$ hydrocarbon product formation in thiophene hydrodesulfurization over $\mathrm{Co}_{0.05} \mathrm{Mo}_{0.975} \mathrm{~S}_{2}, \mathrm{Co}_{0.1} \mathrm{Mo}_{0.95} \mathrm{~S}_{2}, \mathrm{Co}_{0.2} \mathrm{Mo}_{0.9} \mathrm{~S}_{2}$, and $\mathrm{Co}_{0.3} \mathrm{Mo}_{0.85} \mathrm{~S}_{2}$ model catalysts at $523 \mathrm{~K}$. The turnover frequencies obtained at this temperature were betwecn $4 \times 10^{-6}$ and $1.2 \times 10^{-5} \mathrm{~s}^{-1}$.

$\mathrm{MoS}_{2}$ and $\mathrm{Co}_{0.2}+\mathrm{Mo}_{0.9} \mathrm{H}_{2} \mathrm{~S}$, in which it is demonstrated that samples with identical surface areas have vastly different Arrhenius plots.

The product distributions of different hydrocarbons resulting from the hydrodesulfurization of thiophene are given in Figs. 7 and 8. All data shown in these two figures were collected within a narrow range of turnover frequencies at comparable levels of conversion. Isobutene and butadiene could not be separated under our experimental conditions and Figs. 7 and 8 show the sum of these two products.

Large differences in product distributions were observed among the different groups of catalysts. $\mathrm{MoS}_{2}$ and the mechanical mixture " $\mathrm{Co}_{0.2} \mathrm{Mo}_{0.9}+\mathrm{H}_{2} \mathrm{~S}$ " showed similar behavior, except for the lack of isobutene and butadiene in the product spec- trum obtained over the mechanical mixture. Instead, the mechanical mixture gave a higher amount of 1-butene (Fig. 8). Under comparable reaction conditions, the catalyst samples $\mathrm{Co}_{0.5} \mathrm{Mo}_{0.75} \mathrm{~S}_{2}$ and $\mathrm{Co}_{0.6} \mathrm{Mo}_{0.7} \mathrm{~S}_{2}$ did not produce any propene and showed slightly higher selectivity for 1-butene, and trans- and cis-butene. Isobutylene or butadiene was formed only over $\mathrm{MoS}_{2}$, but not over any of the other catalysts.

The product distributions for the four highly active samples with lower Mo/Co ratios (Fig. 7) show a total absence of propene reminiscent of the results obtained on the two samples $\mathrm{Co}_{0.5} \mathrm{Mo}_{0.75} \mathrm{~S}_{2}$ and $\mathrm{Co}_{0.6}$ $\mathrm{Mo}_{0.7} \mathrm{~S}_{2}$. Furthermore, on all four of these catalysts $n$-butane is the main reaction product with more than $50 \%$ selectivity. The increase in $n$-butane selectivity is accomplished largely at the expense of 1-bu- 


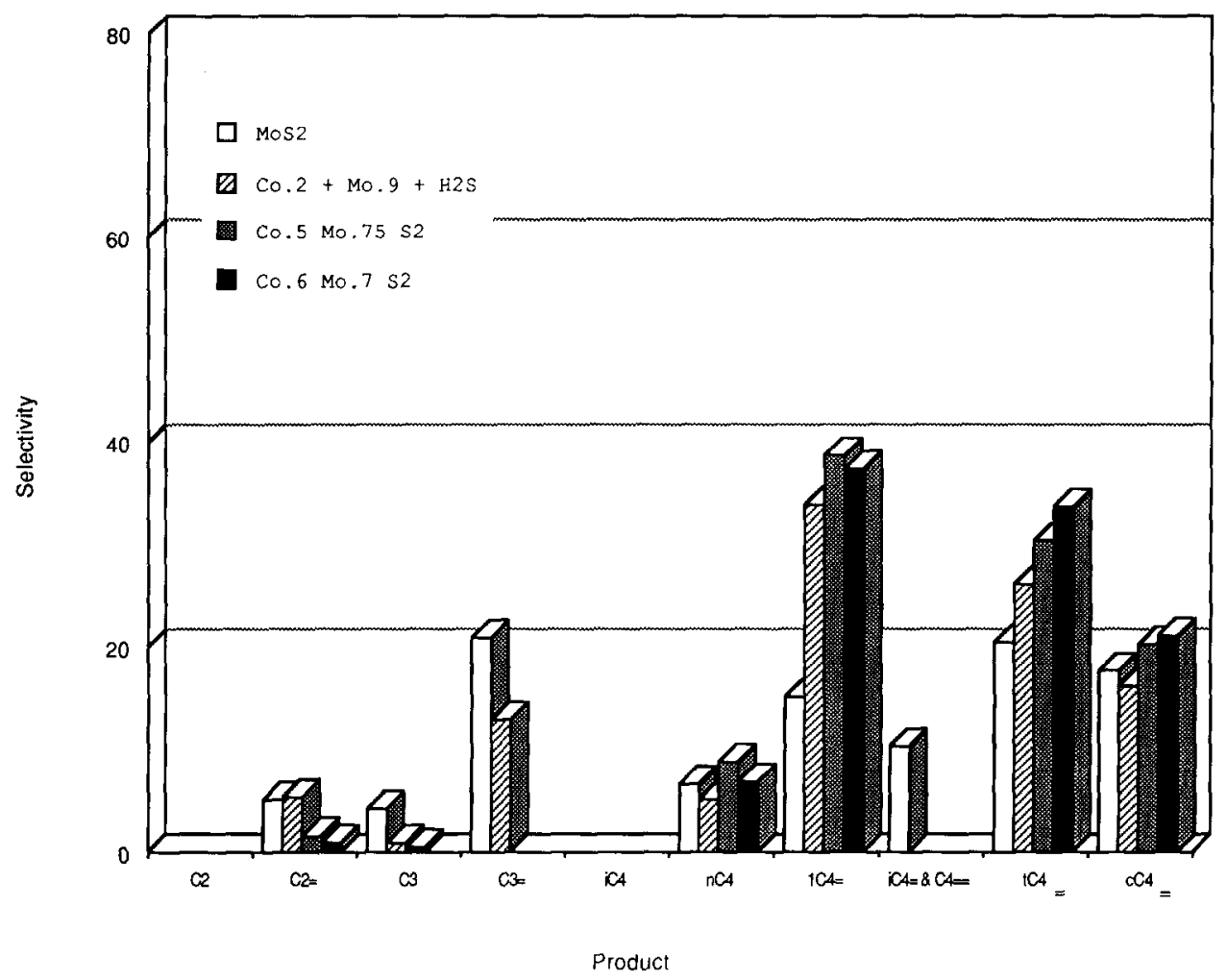

FIG. 8. Selectivity for $\mathrm{C}_{2}, \mathrm{C}_{3}$, and $\mathrm{C}_{4}$ hydrocarbon product formation in thiophene hydrodesulfurization over catalysts $\mathrm{Co}_{0.5} \mathrm{Mo}_{0.75} \mathrm{~S}_{2}, \mathrm{Co}_{0.6} \mathrm{Mo}_{0.7} \mathrm{~S}_{2}$, " $\mathrm{Co}_{0.2} \mathrm{Mo}_{0.9}+\mathrm{H}_{2} \mathrm{~S}$," and $\mathrm{MoS}_{2}$ at $623 \mathrm{~K}$. The turnover frequencies obtained at this temperature were between $5.44 \times 10^{-7}$ and $6.32 \times 10^{-6} \mathrm{~s}^{-1}$.

tene. It is reasonable to assume that the presence of metallic Mo increased the hydrogen transfer capability in samples $\mathrm{Co}_{0.05}$ $\mathrm{Mo}_{0.975} \mathrm{~S}_{2}$ through $\mathrm{Co}_{0.3} \mathrm{Mo}_{0.85} \mathrm{~S}_{2}$, resulting in enhanced formation of saturated $n$-butane. The nonstoichiometric $\mathrm{MoS}_{1.95}$ sample had even higher selectivity for $n$-butane due to the presence of unreacted metallic molybdenum.

\section{CONCLUSIONS}

A solid-state synthesis procedure similar to that reported earlier by Farragher and Cossee (5) in their study of hydrogenation activity of molybdenum and tungsten sulfides has been used to create model HDS catalysts. This preparation proccdure cnsures that the resulting catalysts will be at the very least thermally stable under the HDS reaction conditions used in our sys- tem. Wc have identificd a nonstoichometric phase in our unsupported samples prepared by solid-state reactions of the elements cobalt, molybdenum, and sulfur at $783 \mathrm{~K}$. The nonstoichiometric phase was found in samples having a Co/Mo atomic ratio between 0 and $\mathbf{0 . 3 5 3}$, and it is important to note that the formation of this phase could be achieved by either adding small quantities of a promoter atom to the synthesis charge or by making a sulfur-deficient species such as $\mathrm{MoS}_{1.95}$. The presence of this phase coincided with significantly enhanced hydrodesulfurization activity. X-ray diffraction and selected area electron diffraction results indicate that the new phase is very similar to nonstoichiometric molybdenum sulfide. On the basis of these results, addition of cobalt in certain atomic ratios appears to facilitate the creation of anionic sulfur vacancies in 
$\mathrm{MoS}_{2}$ with the consequence of enhanced HDS activity.

\section{REFERENCES}

1. Lipsch, J. M. J. G., and Schuit, G. C. A., J. Catal. 15, 179 (1969).

2. Gates, B. C., Katzer, J. R., and Schuit, G. C. A., in "Chemistry of Catalytic Processes," Chapter 5. McGraw-Hill, New York, 1979.

3. Massoth, F. E., J. Catal. 36, 154 (1975).

4. Voorhoeve, R. J. H., and Stuiver, J. C. M., J. Catal. 23, 243 (1971).

5. Farragher, A. L., and Cossee, P., in "Proceedings, 5th International Congress on Catalysis, Palm Beach, 1972" (J. W. Hightower, Ed.), p. 1301. North-Holland, Amsterdam, 1973.

6. Hagenbach, G., Courty, P., and Delmon, B., $J$. Catal. 23, 295 (1971).

7. Delmon, B., Amer. Chem. Soc. Div. Pet. Chem. Prepr. 22, 503 (1977).

8. Hagenbach, G., Courty, P., and Delmon, B., $J$. Catal. 31, 264 (1973).

9. Topsøe, H., Clausen, B. S., Candia, R., Wivel, C., and Mørup, S., J. Catal. 68, 433 (1981).

10. Wivel, C., Candia, R., Clausen, B. S., Mørup, S., and Topsøe, H., J. Catal. 68, 453 (1981).

11. Chianelli, R. R., Catal. Rev. Sci. Eng. 26, 361 (1984).

12. Topsøe, H., and Clausen, B. S., Catal. Rev. Sci. Eng. 26, 395 (1984).

13. Breysse, M., Bennet, B. A., Chadwick, D., and Vrinat, M., Bull. Soc. Chim. Belg. 90, 1271 (1981).

14. Candia, R., Clausen, B. S., and Topsøe, H., J. Catal. 77, 564 (1982).

15. Clausen, B. S., Mфrup, S., Topsøe, H., and Candia, R., J. Phys. Colloq. 37, C6-249 (1976).

16. Alstrup, I., Chorkendorff, I., Candia, R., Clausen, G. S., and Topsøe, H., J. Catal. 77, 397 (1982).

17. Sankar, G., Sarode, P. R., Srinivasan, A., Rao, C. N. R., Vasudevan, S., and Thomas, J. M., Proc. Indian Acad. Sci. Chem. Sci. 93, 321 (1984).
18. Clausen, B. S., Topsøe, H., Candia, R., Villadsen, J., Lengler, B., Als-Nielsen, J., and Christensen, F., J. Phys. Chem. 85, 3868 (1981).

19. Boudart, M., Sanchez-Arrieta, J., and Dalla Betta, R., J. Amer. Chem. Soc. 105, 6501 (1983).

20. Sankar, G., Vasudevan, S., and Rao, C. N. R., J. Phys. Chem. 91, 2011 (1987).

21. Sorensen, O., Clausen, B. S., Candia, R., and Topsøe, H., Appl. Catal. 13, 363 (1985).

22. Pollack, S. S., Sanders, J. V., and Tischer, R. E., Appl. Catal. 8, 383 (1983).

23. Candia, R., Clausen, B. S., and Topsøe, H., Bull. Soc. Chim. Belg. 90, 1225 (1981).

24. Topsøe, N. Y., and Topsøe, H., J. Catal. 84, 386 (1983).

25. Konings, A. J. A., Valster, A., de Beer, V H. J., and Prins, R., J. Catal. 76, 466 (1982).

26. Derouane, E. G., Pederson, E., Clausen, B. S., Gabelica, Z., Candia, R., and Topsøe, H., J. Catal. 99, 253 (1986).

27. Silvy, R. P., Delannay, F., Grange, P., and Delmon, B., Polyhedron 5, 195 (1986).

28. Topsøe, H., Clausen, B. S., Topsøe, N. Y., and Pederson, E., Ind. Eng. Chem. Fund. 25, 25 (1986).

29. Chianelli, R. R., Pecoraro, T. A., Halbert, T. R., Pan, W. H., and Stiefel, E. I., J. Catal. 86, 226 (1984).

30. Göbölös, S., Wu, Q., and Delmon, B., Appl. Catal. 13, 89 (1984).

31. Ergun, S., Phys. Rev. B 1, 3771 (1970).

32. Vrinat, M. L., and De Mourgues, Appl. Catal. 5, 43 (1983).

33. Ledoux, M. J., Maire, G., Hantzer, S., Michaux, O., in "Proceedings, 9th International Congress on Catalysis, Calgary, 1988" (M. J. Phillips and M. Ternan, Eds.), Vol. 1, p. 74. Chem. Institute of Canada, Ottawa, 1988.

34. Lindner, J., Sachdev, A., Villa-Garcia, M. A., and Schwank, J., in "Proceedings, Electron Microscopy Society of America, San Antonio, TX, 1989." 